\section{$\underset{\substack{\text { hommes } \\ \text { \& migrations }}}{ }$}

\section{Hommes \& migrations}

Revue française de référence sur les dynamiques

migratoires

$1306 \mid 2014$

Ecriture et migration

\title{
Carole Zalberg, Feu pour feu,
}

Paris, Actes Sud, 2014, 72 pages, 11,50€.

\section{Mustapha Harzoune}

\section{(2) OpenEdition}

1 Journals

\section{Édition électronique}

URL : http://journals.openedition.org/hommesmigrations/2833

DOI : 10.4000/hommesmigrations.2833

ISSN : 2262-3353

\section{Éditeur}

Musée national de l'histoire de l'immigration

\section{Édition imprimée}

Date de publication : 1 avril 2014

Pagination : 123-123

ISBN : 978-2-919040-27-8

ISSN : $1142-852 X$

Référence électronique

Mustapha Harzoune, « Carole Zalberg, Feu pour feu, », Hommes \& migrations [En ligne], 1306 | 2014, mis en ligne le 06 août 2014, consulté le 22 septembre 2020. URL : http://journals.openedition.org/ hommesmigrations/2833; DOI : https://doi.org/10.4000/hommesmigrations.2833

Ce document a été généré automatiquement le 22 septembre 2020.

Tous droits réservés 


\title{
Carole Zalberg, Feu pour feu,
}

\author{
Paris, Actes Sud, 2014, 72 pages, 11,50€.
}

\section{Mustapha Harzoune}

\section{RÉFÉRENCE}

Carole Zalberg, Feu pour feu,

Paris, Actes Sud, 2014, 72 pages, 11,50€.

\section{NOTE DE L'ÉDITEUR}

Sélection 2014 de la $5^{\mathrm{e}}$ édition du prix littéraire de la Porte Dorée

1 S'il fallait une porte d'entrée à ce court texte, ce serait l'amour d'un père pour sa fille. Bien sûr, ce roman évoque l'exil et l'intégration. Mais là où Carole Zalberg secoue, émeut, bouleverse même, c'est dans la description qu'elle fait du lien qui unit un père à sa fille.

2 Adama est encore bébé quand son père tente d'échapper à un massacre qui a déjà décimé les siens, à commencer par son épouse. Ils fuient, et dans cette course contre la mort, “j'ai deux cœurs au travail”, dit le père. Il porte son enfant mais très vite la question se pose : qui soutient qui ? qui protège qui ? Le père ou l'enfant? "Je te cale serrée au creux de mon aisselle, te couvre sans peser. Je suis ton monde et tant que ta peau le perçoit, tant que tu me respires, m'avales presque, tu ne sais pas que tu as faim et soif." Et pourtant, c'est elle qui devient son unique raison de vivre : "ma vie, depuis le jour où tout ce que j'avais jamais aimé en dehors de toi fut détruit, a été ton embarcation. Uniquement cela. Tout cela".

3 Feu pour feu déroule le récit de cette fuite et l'installation en France, "entre des tours grises et délabrées" devenues apparent refuge. En contrepoint, un autre feu, "un feu meurtrier", va rattraper le père et sa fille. Il brûle, et en un instant, un instant d'égarement, réduit en cendre le fragile mur de "bonheur", à tout le moins de "paix", 
que, tout au long des quinze années d'exil, le père a dressé, jour après jour, pour préserver sa fille du malheur. Il a cru bien faire en prodiguant mille et une précautions, mille et une protections, mille et une délicatesses. Il a cru bien faire en allant jusqu'à taire l'histoire passée: "Je ne voulais pas que tu partages ma douleur. Je voulais que pour toi au moins tout commence ici." Sauf que, sans s'en rendre compte, le père avait perdu sa fille. Sauf qu'un feu peut tout emporter. Restent le doute, la culpabilité. La souffrance.

Des incises, comme autant de lames, lacèrent le récit paternel. Ce sont les mots de l'enfant devenue adolescente. Des mots censés être ceux d'une gamine de cité. Ce n'est pas la partie la plus heureuse de ce texte. L'idée de ce dialogue à distance, porté par des langues différentes, était bonne, la réalisation beaucoup moins. Trop fabriqué pour peu même que les jeunes des "técis" s'expriment comme Adama...

5 Feu pour feu parle de l'amour quasi sacrificiel d'un père pour sa fille, des ressorts mystérieux non pas du bonheur mais d'un certain équilibre entre un passé dramatique et un présent d'incertitude, de la place du silence et de l'oubli, de la nécessité de dire et de transmettre, des pièges aussi que dresse une société sur la voie non pas de l'intégration, mais de l'intégrité et de la résilience. "Ne nous battons-nous pas jour après jour, mois, année, dès notre arrivée dans ce pays? Ne sommes-nous pas des greffons exemplaires, absorbant ce qu'il y a à absorber de notre hôte, mots, institutions, usages, afin de ne pas être rejetés? Je le fais pour nous deux, au commencement, avec conscience et acharnement. Je nous fonds. J'ai su passer pour mort au milieu des morts, je peux bien mimer tout ce qu'il y a à mimer pour avoir le droit de vivre ici. Pour que ça prenne." Quelques clichés et un certain angélisme dans la balance entre Afrique et Europe traversent le texte qui, avec plus de pertinence, pointe les ambiguïtés de l'humanitaire - "nos malheurs sont une promesse de hauteur" pour les "aspirants à la sainteté" - et dénonce cette façon de traiter les migrants "non comme des hommes mais comme une maladie". 